\title{
Community Empowerment in Plempoh Cultural Tourism Village
}

\author{
Angger Hidayat ${ }^{1 *}$, Myrza Rahmanita $^{2}$, Henky Hermantoro ${ }^{3}$ \\ 1,2,3 Sekolah Tinggi Pariwisata Trisakti \\ *angger_bidayat@yahoo.com
}

\begin{abstract}
Plempoh Cultural Tourism Village possesses a unique attraction such as natural resources and cultural heritage. Collaborating with the government, entrepreneurs, academicians and media, a group of tourism awareness called Pokdarwis Prabu Boko appears to be the central group behind every development of the Plempoh Cultural Tourism Village. However, previous research reveals that poverty still appears in this village, there is lack of community confidence and knowledge related to tourism; and lack of community participation in developing the village. This research aims to study the realization and the level of community empowerment in terms of economical, psychological, social and political aspect. This research used qualitative paradigm with descriptive method and purposive sampling technique. Data is collected using interview technique, observation and documentation. The data is then validated using source triangulation. The result shows that the community empowerment efforts undertaken by village stakeholders have not been optimal because some of the tourism village stakeholders still have not given strong commitment and they have not received trust from local communities. However, there are some evidence of community empowerment progress as follows: (1) the economic empowerment has now reached the fourth stage, namely support level. (2) the psychological empowerment is at the second stage, called reinforcement; (3) the social empowerment of the community is at its fifth stage, namely Maintenance, (4) the political empowerment is at the lowest level, namely possibility.
\end{abstract}

Keywords: community empowerment, cultural tourism village, Plempoh

TRJ Tourism Research Journal, Volume 1 (1), 2017 


\section{A. Introduction}

Plempoh Cultural Tourism Village is located in Bokoharjo, Prambanan Subdistrict, Sleman Regency. It possesses a unique attraction such as natural resources and cultural heritage that appears as an asset of attraction, combined with cultural traditions such as Srandul; a drama focusing on Dadung Awuk with traditional music assembly (Ramafriani, 2012). Such attraction appears as the basic investment in the development of Plempoh Cultural Countryside Tourism..

Pokdarwis Prabu Boko is one of the main trustees for the community empowerment in the Plempoh Cultural Tourism Village project. Collaborating with the government, entrepreneurs, academicians and media, Pokdarwis Prabu Boko appears as a central group behind every development of the Plempoh Cultural Tourism Village by creating an economical, psychological, social and political upgrade of the people in the region.

Apparently, based on several researches related to the development of Plempoh Cultural Tourism Village, poverty still appears among the society. Economically, Plempoh Cultural Tourism Village has not been able to provide extra income for the society. Psychologically, the society still possesses the lack of confidence and knowledge related to tourism; based on the community empowerment, the main problem appears to be the apathy generated by the people and the lack of trust towards Pokdarwis Prabu Boko (Wijaya, 2009); the economical, psychological, social, and political lack of aspect from the community empowerment of the Plempoh Cultural Tourism Village do not only appear as the only problem, but the lack of participation of the people in creating decision which results in unrealized events is also the cause of poverty occurring in the society (Martono, Pujiastuti, Pratiwi, \& Chrysandi, 2013).

Based on the background, there are indications that the people of Plempoh Cultural Tourism Village still experience lack of economical, psychological, social, and political standard by the main communities, especially relating to the role of Pokdarwis Prabu Boko which is supposed to develop the Plempoh Cultural Tourism Village. There are several indications related to the lack of community empowerment such as: (1) economically, unsuccessfulness in providing an income upgrade towards the society; (2) psychologically, the lack of confidence and knowledge of tourism among the people; (3) socially, the existence of apathy by the people due to the lack of trust towards the Pokdarwis Prabu Boko; (4) politically, the unrealized programs by the people due to the lack of decision making and participation.

The purpose of this research is to study the reality and the level of the community empowerment in the Plempoh Cultural Tourism Village relating to the economical, psychological, social and political aspect of all involved communities, including Pokdarwis Prabu Boko. Moreover, this research is also to identify all efforts done by communities in the development of Plempoh Cultural Tourism Village including the government, academician, entrepreneurs and media.

TRJ Tourism Research Journal, Volume 1 (1), 2017 


\section{B. Literature Review}

A number of definitions of destinations defined by some specific sources include "... the place where tourists intends to spend their time away from home" (Jafari in Hermantoro, 2015: 108), "an amalgam of products and services available in one location that can draw visitors from beyond its spatial confines "(Pearce in Hermantoro, 2015: 108). Tourism destinations can also be seen as a planning area and referred to as a community tourism or destination zone (Gunn \& Var in Hermantoro, 2015: 108). A destination must have various facilities needed by the needs of tourists to visit so needs can be fulfilled and comfortable. Various tourist needs are, among others, transportation facilities, accommodation, travel agencies, attractions (food, recreation, and entertainment), food service, and souvenir items (Pitana \& Gayatri, 2005: 101).

In order to establish the development of sustainable tourism destinations based on democracy, it is necessary to diversify the tourist attraction oriented towards improving the welfare of the people, the preservation of recreational art, the development of environmentally friendly tourism and able to preserve local culture (Nalayani, 2016; Kemenbudpar, 2011 : 13). Tourist village is one of the right choices in forming a rural tourism area that can be used as a tourist attraction.

Tourism Village with cultural appeal is seen as a rural area unit with the uniqueness of various elements of traditional customs and peculiarities of daily life of the community inherent as a cultural form of rural society, whether related to livelihood activities, religion and other forms of activity. (Dinpar DIY, 2014: 2-6). Furthermore, cultural tourism attraction can be elaborated including tangible and intangible tourist attraction. (PP RI No. 50 Year 2011)

In the planning of a tourist village, community empowerment is very important because in addition to the community's rights in planning, the local people also know better what to do and what is not in line with local conditions. (Tosun \& Timothy in Smith \& Robinson, 2005: 94). The empowerment of rural tourism community is a political control capability by the village tour administrators that involve the community with the aim that the community gets the opportunity to participate in improving their welfare. (Stetic, Pavlovic, Stanic \& Simicevic, 2014; Maton in Li \& Hunter, 2015)

Village tourism development activities as an effort to empower communities, in essence involves the role of all existing and related stakeholders. Stakeholders in question include 5 (five) parties namely: government, community, employers, academicians and media, with all their respective roles and functions.

The descriptive roles and functions of each of these stakeholders are more clearly stated as follows.

1. The Government is in accordance with its duties and authority to perform its role and function as a facilitator and regulator in tourism village development activities.

TRJ Tourism Research Journal, Volume 1 (1), 2017 
2. Community as an object as well as the subject of development is imperative to still play an active role. Communities with possessed resources, whether in the form of customs, traditions and culture and capacity, acting as host, but also at the same time have the opportunity as the perpetrator of the development of tourist village according to the ability it has.

3. Media such as digital online, TV broadcasting, radio, or print media is the best means in transmitting the content of a tourist village to tourists with a very wide coverage.

4. Entrepreneurs with the resources, funding and networks they possess perform their roles and functions as developers and or executors of the development of village tourism activities;

5. Academics appear as an analyst of the impact of improving the welfare of the community due to the development of tourist villages and doing research on the development effect.

The management of tourist villages in Indonesia is implemented through an informal institutional system formed by community members (especially those concerned with developing tourism in their area) and is one of the stakeholder elements as well as a driving force in the community that has an important relationship and role in developing and realizing an atmosphere with comfort at the local level in the region, which collectively will have a positive impact on the development of tourism destinations within the broader context (Kemenparekraf, 2012). Here is the scheme of informal institutional establishment of tourist village management on the initiative of the community which this informal institution is further known as Pokdarwis / Aware tourism aware group.

Community planning and development by Pokdarwis can be implemented through four empowerment frameworks that can serve as a benchmark, designed to provide mechanisms that enable the effectiveness of tourism initiatives that impact on local communities, and can be used by communities and development agencies that plan community involvement in tourism businesses (Scheyvens, 1999). Here are four frameworks of empowerment according to Scheyvens.

\section{Economic Empowerment}

The economically powerless community is able to develop all the potential possessed to be the optimal tourist attraction of the village. This is characterized by the ability of the community to interact with outside communities, exchange goods with other areas and the ability to influence each other in other regions (Maryani \& Waluya, 2016). The improvement of tourist village economy can be known from the changes before and after the village become a tourist village. These changes can be seen from community activities in entrepreneurial tourism sector, additional revenues beyond the main livelihood income and the number of available employment. (Purnamasari, 2011). 


\section{Psychological Empowerment}

Local people who are optimistic about the future, have confidence in their abilities, are relatively independent, and show pride in cultural traditions can be said to be very strong psychologically. Traditional preservation is essential in maintaining the confidence and well-being of small and unindustrialized community groups. Tourism that is sensitive to cultural norms and builds respect for local traditions can empower local people. On the other hand, tourism that disrupts socio-cultural life such as disturbing the integral relationship between a group of people and their lands, may have adverse effects (Scheyvens, 1999).

\section{Social Empowerment}

Social empowerment refers to the integration between community groups through tourism activities with various typologies. Strong community groups, including youth groups, spiritual groups and women's groups, are signs of empowered communities. Social empowerment through tourism is seen when the benefits of tourism activities are used to fund social development projects, such as irrigation systems, health clinics, and means of worship (Scheyvens, 1999).

\section{Political Empowerment}

If a community is politically empowered through tourism, their voices and their concerns should guide the development of a tourism project from planning stage to its implementation, without the participation of the community, tourism planning and development will never happen (Scheyvens, 1999; Purnamasari, 2008: 51-52). Various interest groups within a community, including women and youth, should also have representation in the wider community decision-making process. Akama in Scheyvens (1999) argues that for local people to be able to exercise control over tourism activities, power needs to be decentralized from national to community level. Political disempowerment arises because of the negative power that involves domination and coercion against others. This practice depends on the idea that power is limited and not generative, so empowering one individual or multiple individuals through dominance simultaneously results in powerlessness for others (Knight, 2015).

In order to find out how far the planning and development of society by the board of the village tour/Pokdarwis, it can be seen through 5 stages in the community empowerment (Suharto in Suharto, 2006), namely:

1. Possibility: Creating an atmosphere or climate that allows the potential of society to develop optimally and able to free the society from cultural and structural barriers.

2. Strengthening: Strengthening knowledge and ability possessed by society in solving problem and fulfilling requirement. Empowerment should be able to develop all the capabilities and confidence of the community that supports independence.

TRJ Tourism Research Journal, Volume 1 (1), 2017 
3. Protection: Protect the community especially weak groups for not being oppressed by stronger groups, avoid unbalanced competition between the strong and the weak, and prevent the exploitation of strong groups against weak groups and eliminate any kind of unfavorable discrimination.

4. Support: Provide guidance and support so that people are able to carry out the roles and tasks of their lives. Empowerment must be able to support the community not to fall in a state and position that becomes weaker and marginalized.

5. Maintenance: Maintaining a comfortable condition in order to maintain balance of the power distribution between different groups in society. Empowerment must be able to ensure the balance that allows everyone to have a chance to work.

A number of global studies on community empowerment include Magigi \& Ramadhani (2013) which emphasizes participatory tourism development. The success of the tourism industry in Bwejuu Village and Zanzibar in bringing tourists cannot be separated from the active involvement and participation of the community as a central stakeholder supported by thr policy and act regulation as well as investment in building infrastructure and public facilities from the local government. The quality of human resources in tourism development also plays a very important role in Girokastra Albania which has the direction of developing cultural tourism (Qiqi \& Rova, 2014).

Community empowerment of several tourist villages in Indonesia is implemented through informal group of tourism awareness which is divided into three parts namely, tourist attraction form, improvement of human resource quality in tourism attraction management and improvement of quality and quantity of tourism attraction facility. The role of the most crucial tourism awareness group in Tembi Tourism Village is the development of attraction program (Putra, 2013). In the implementation of community empowerment through the tourism awareness group sometimes still leaves several problems related to Pokdarwis organizational structure to its role and function as well as the uncertainty between elements and Pokdarwis sector in carrying out tourism like in Karangrejo Village (Sofianto, 2013).

With the role of the tourism conscious group as the driving force, the role of the local community is a key element in the existence of the powerless community in improving the potential of tourist villages, such as the role of local communities in Jatiluwih Tourism Village which, among others (1) provides most attractions while determining product quality tours. Traditional farmland management, traditional ceremonies, handicrafts and hygiene are some examples of roles that provide attraction to tourism; (2) cultural actors, for example, art that become one of the tourist attractions; and (3) accommodation providers and tour guide services, labor supply, specialty food products, handicrafts and local art, etc. (Dewi, Fandeli \& Baiquni, 2013).

Empowerment can be analyzed and seen through the four elements that

TRJ Tourism Research Journal, Volume 1 (1), 2017 
Scheyvens proposed, namely: Economics, Psychology, Social and Politics. The following is a description of the principal relationship of each variable in this study in accordance with the concept of community empowerment.

\section{Research Methodology}

The researcher uses qualitative paradigm with descriptive method and purposive sampling as technique of sampling. Sample collection is done by interview technique, observation and documentation. The data that has been collected is then validated using source triangulation.

In this research, there are two ontological aspects, namely: (1) exploring the process of community empowerment of Cultural Tourism Village of Plempoh and its achievement which is studied through 4 levels of empowerment; economic, psychology, social and politics, (2) deep observation on the impact of tourism village initiative culture to the local community presented as a measure of how far the existing empowerment is in a society.

In the context of epistemology, the task of researchers is to search the data and analyze it from the point of view of the community and administrators of the Cultural Tourism Village of Plempoh, so how social interactions and dynamics shaped their understanding of the concept of community empowerment through the Cultural Tourism Village Plempoh can be seen. Thus, the researchers tried to interpret the findings based on the worldview used by the community and village tour administrators. In essence, this paradigm is trying to reveal how the social reality community empowerment in Plempoh Culture Village is maintained by certain individuals and how they interpret it as an effort to optimize Plempoh culture.

Table 1. Ontologies and Epistemology Aspect in this Research

Community Empowerment Framework

\begin{tabular}{clc}
\hline Ontologies & \multicolumn{1}{c}{ Epistemology } & Methodology \\
\hline Economy & - Capital Assistance & Interview \\
& - Assurance of business opportunity & \\
\hline Psychology & - Situation that supports tourism potential & Interview \\
& - Efforts to increase confidence & \\
& - Community skill and knowledge & Interview \\
\hline Social & - Training skill & \\
\hline Politic & - Level of discrimination among community & Interview \\
& - Freedom to express opinion & \\
\hline
\end{tabular}


Empowered Indicator

\begin{tabular}{|c|c|c|}
\hline Aspects & Sign of Empowerment & Sign of Disempowerment \\
\hline \multirow{11}{*}{ Economy } & Tourism brings lasting & \multirow{11}{*}{$\begin{array}{l}\text { Tourism merely results in small, } \\
\text { spasmodic cash gains for a local } \\
\text { community. Most profits go to } \\
\text { local elites, outside operators, } \\
\text { government agencies, etc. Only a } \\
\text { few individuals or families gain } \\
\text { direct financial benefits from } \\
\text { tourism, while others cannot find } \\
\text { a way to share in these economic } \\
\text { benefits because they lack } \\
\text { capital and/or appropriate skills. }\end{array}$} \\
\hline & economic gains to a local & \\
\hline & community. Cash earned is & \\
\hline & shared between many & \\
\hline & households in the community. & \\
\hline & There are visible signs of & \\
\hline & improvements from the cash & \\
\hline & that is earned & \\
\hline & & \\
\hline & & \\
\hline & & \\
\hline \multirow{16}{*}{ Psychology } & Self-esteem of many & \multirow{16}{*}{$\begin{array}{l}\text { Many people have not shared in } \\
\text { the benefits of tourism, yet they } \\
\text { may face hardships because of } \\
\text { reduced access to the resources } \\
\text { of a protected area. They are thus } \\
\text { confused, frustrated, } \\
\text { disinterested or disillusioned } \\
\text { with the initiative. }\end{array}$} \\
\hline & community members is & \\
\hline & enhanced because of outside & \\
\hline & recognition of the uniqueness & \\
\hline & and value of their culture, their & \\
\hline & natural resources and their & \\
\hline & traditional knowledge. & \\
\hline & Increasing confidence of & \\
\hline & community members leads & \\
\hline & them to seek out further & \\
\hline & education and training & \\
\hline & opportunities. Access to & \\
\hline & employment and cash leads to & \\
\hline & an increase in status for & \\
\hline & traditionally low-status sectors & \\
\hline & of society. & \\
\hline \multirow{14}{*}{ Social } & Tourism maintains or enhances & \multirow{5}{*}{$\begin{array}{l}\text { Disharmony and social decay. } \\
\text { Many in the community take on } \\
\text { outside values and lose respect } \\
\text { for traditional culture and for } \\
\text { elders. Disadvantaged groups } \\
\text { (e.g. women) bear the brunt of }\end{array}$} \\
\hline & the local community's & \\
\hline & equilibrium. Community & \\
\hline & $\begin{array}{l}\text { cohesion is improved as } \\
\text { individuals and families work }\end{array}$ & \\
\hline & \multirow{10}{*}{$\begin{array}{l}\text { together to build a successful } \\
\text { tourism venture. Some funds } \\
\text { raised are used for community } \\
\text { development purposes. }\end{array}$} & \\
\hline & & problems associated with the \\
\hline & & tourism initiative and fail to \\
\hline & & share equitably in its benefits. \\
\hline & & Rather than cooperating, \\
\hline & & individuals, families, ethnic or \\
\hline & & socio-economic groups compete \\
\hline & & with each other for the perceived \\
\hline & & benefits of ecotourism. \\
\hline & & Resentment and jealousy are \\
\hline
\end{tabular}


commonplace.

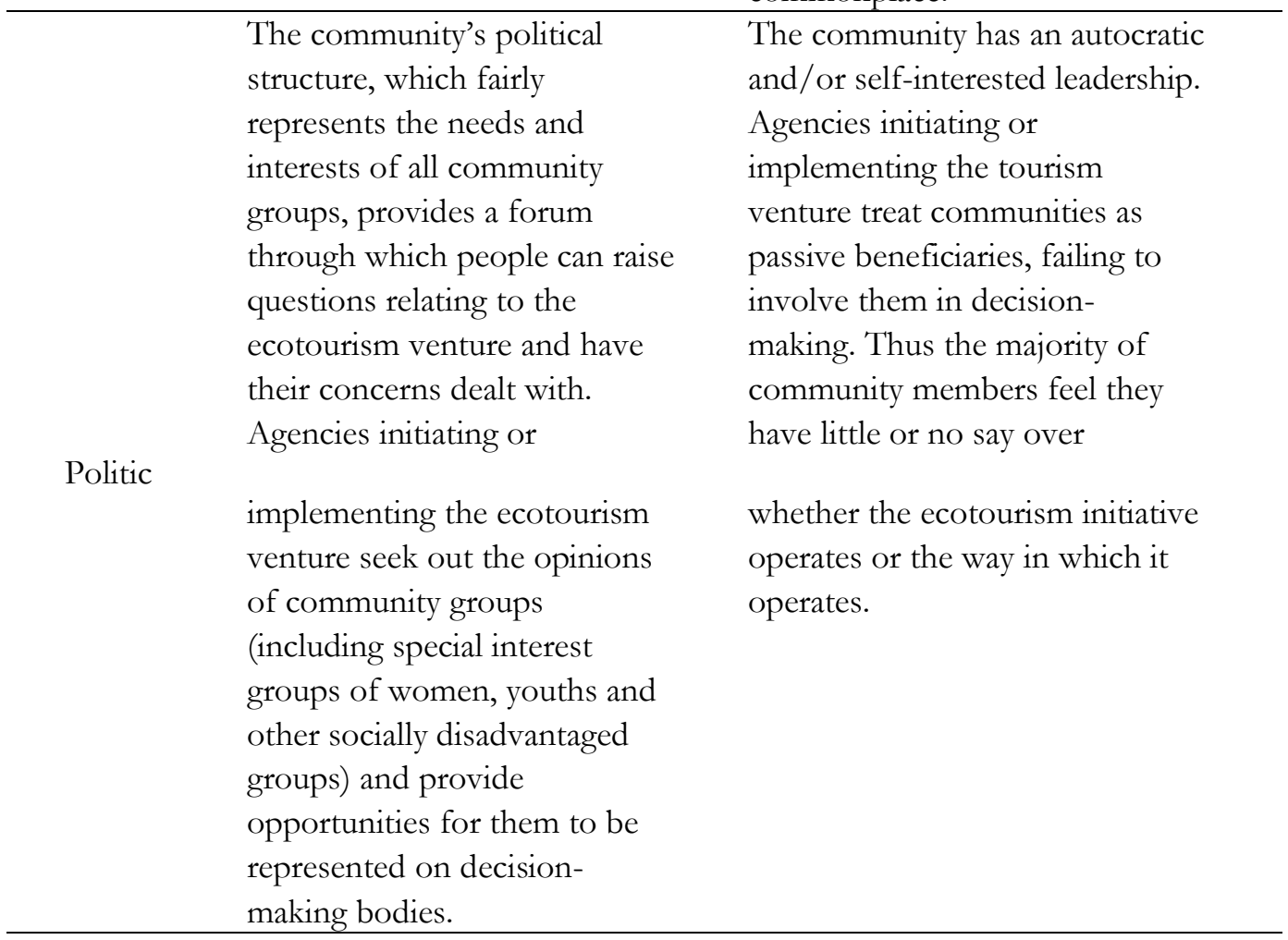

Source: Scheyvens, 1999.

The research is conducted in Plempoh Cultural Tourism Village which is administratively located in Bokoharjo Village, Prambanan Subdistrict, Sleman Regency, Yogyakarta Province. The reason for choosing the location for this research is due to the lack of research conducted by the academicians related to the process of empowering the community of Bokoharjo Village through Plempoh Cultural Tourism Village. This research is conducted within 5 months, from January 2017 to May 2017.

\section{Result and Discussion}

Based on the geographical hierarchy set forth in Sleman District Spatial Plan of 2011-2031, Bokoharjo Village in particular and Prambanan Sub-district generally enter the criteria of the supportive villages of Prambanan and Ratu Boko Sites. So that the Village Plempoh and Padukuhan Dawung, Bokoharjo Village which is the dominant area of Ratu Boko Site becomes more determined and developed into a tourist village that has a selling point.

Administratively, Plempoh Village is directly adjacent to:

a. North side is bordered by Padukuhan Ringinsari, Bokoharjo Village

b. The south is bordered by Padukuhan Marangan, Bokoharjo Village

c. The west is bordered by Manoh Jobohan, Bokoharjo Village

TRJ Tourism Research Journal, Volume 1 (1), 2017 
d. The east is bordered by Padukuhan Cepit, Bokoharjo Village

Plempoh Village is one of 13 groups in Bokoharjo Village, with 153 families with the population of 449 people. In addition to agriculture and livestock, the people of Plempoh Village also benefit geographically with the presence of Ratu Boko Site that brings new business opportunities that affect the surrounding community. Efforts to increase access to Ratu Boko Site from the government also have a positive impact such as facilitating transportation and mobility.

Plempoh development as a tourist village is said to be advanced and contributive to the economy of the community if it is able to develop all the potential tourist attraction of the village optimally. Cultural Tourism Village of Plempoh has a unique tourist attraction in the form of physical attractiveness of the natural environment consisting of rice fields, hills and bordered directly with the Site of Ratu Boko Palace as an asset of cultural heritage sites as well as social and cultural life of the community with the whole customs and cultural traditions. These potentials can be developed as a tourist attraction and are the basic capital for the development of the Cultural Tourism Village of Plempoh which must be supported by the spirit and strong motivation of the community and the management of the tourism village/Pokdarwis in maintaining, preserving and ensuring the sustainability of natural and cultural characteristics.

In an effort to develop the Cultural Tourism Village of Plempoh, the empowerment of the community appears imperative. Local people know better about what to do and what is not in accordance with local conditions. Planning and development of village communities by administrators of the Cultural Tourism Village of Plempoh or in this case Pokdarwis Prabu Boko can be analyzed and viewed through the 4 elements that Scheyvens has put forward, namely: Economics, Psychology, Social and Politics as follows.

\section{Economic Empowerment}

Economically, community empowerment by Pokdarwis Prabu Boko through one tourist village can provide several business opportunities to surrounding communities, in addition to groups such as youth groups empowered through gamelan performances, and productive mothers in batik activities. As for the wider community, business opportunities such as food and beverage and parking businesses are obtained from Ratu Boko Site directly managed by PT. TWC.

In general, there is an increase in the economy of Bokoharjo Village which can be seen from the per capita GRDP indicator in Prambanan Subdistrict, which has always increased from 2007 to 2012, respectively from Rp 8,701; Rp 10.051; Rp 12.046; Rp 13.170; Rp 14,365; up to Rp 15,528 in 2012.

In addition to the indicator of PDRB, the existence of processing Industry Company is also very influential on the economic life of the people of Prambanan Sub-district, because the industry is able to create employment. In

TRJ Tourism Research Journal, Volume 1 (1), 2017 
2011, there were 246 small industry companies and 3 large / medium industries, and 263 units of large and medium scale industries in 2012 increased and 270 units small and 4 large / medium industrial units. As one of the important livelihoods for the community, the processing industry sector is expected to absorb a lot of manpower. There are 192 people work in small industries, 117 people work in large and medium-sized industries, and 54 people work in home industries.

\section{Psychological Empowerment}

Global competition and various changes that occur in the development of national tourism require the stakeholders of the Village of Plempoh to have initiative and innovation. The motivational concept of increasing the confidence and ability of the people of Plempoh Village is implemented through various provision of infrastructure and various types of training that support the development of the village. The infrastructure and training facilities that have been implemented include: the procurement of a set of gamelan, art studio development, procurement of homestay supplies assisted by PNPM Mandiri Tourism, dance training in collaboration with ISI Yogyakarta, culinary training held by STP Ampta Yogyakarta, guide training by PT Taman Wisata Candi together with BPCB Yogyakarta, batik training by Pokdarwis Prabu Boko as community coordinator in the village and regular karawitan training

Another way of increasing self-confidence of the community is through the events of competition held by the local government of Sleman and Yogyakarta. One of the competitions held Sleman regency is a karawitan event where the Cultural Tourism Village Plempoh successfully won third place. This has a positive impact on the psychology of the people of the Cultural Tourism Village Plempoh who feel proud of their achievement and their cultural traditions which has received external recognition...

The independence of the community of Cultural Tourism Village of Plempoh in the development of tourism village products in the form of souvenir batik temple motifs and culinary products typical Plempoh chili food is marketed not only in the Plempoh Village, but also in the greater coverage area. Batik with typical temple motifs is often included in the exhibition held in Yogyakarta Province, while culinary products of Plempoh are marketed in several tourism destinations in Yogyakarta by displaying them in Yogya typical culinary outlets.

\section{Social Empowerment}

In the modern digital era, communication and coordination among communities in Plempoh Village are done through electronic media such as whatsapp application. In addition, electronic media is also used by tour administrators to introduce and market the village in the form of blogspot with can be accessed from URL dewita-plempoh.blogspot.com/desaplempoh.blogspot.com and

TRJ Tourism Research Journal, Volume 1 (1), 2017 
Facebook: Plempoh Cultural Tourism Village.

The social integration between communities in Plempoh Village is supported by the existence of joglo building owned by Yogyakarta State University as a social laboratory and joglo owned by PT Taman Wisata Candi located in Ratu Boko Site area and art gallery of PNPM Mandiri donation from Central Government. Cultural Tourism Village of Plempoh also has become a place for academics to do the practical work. Currently, some education institutions conduct internships and service learning in the village

Based on the documentations and observations, it reveals that people of Plempoh Cultural Tourism Village are very enthusiastic to join the program conducted by academicians such as, research and field work practice. Several types of counseling and work programs that have been implemented were determined from health, environmental hygiene, culinary, cooperatives to the extension of tourism awareness.

The awareness of community to strengthen the knowledge and ability to fulfill its needs has been running well, which is coordinated by the management of the Cultural Tourism Village Plempoh together with four stakeholders in pentahelix concept. One of the causes of the increasing awareness of community tourism comes from the management of Ratu Boko Site who has been successful in increasing tourist visit every year.

The social empowerment of the community in the village provides protection for people in needs. Protection is directed at the elimination of any kind of discrimination. However, due to the lack of transparency and coordination between administrators and community, discriminatory feelings still exist within the village community. The duty of the management of the Plempoh Cultural Tourism Village is to create a comfortable atmosphere for mutual coordination and to provide transparency related to the solution by the government in the development of a tourist village.

\section{Political Empowerment}

The distribution of power in the village in a form of political decentralization is manifested through the establishment of a representative body of Prabu Boko's tourism group with all areas under the auspices of the institution. Areas of community development such as security and order, tourist attraction and memories, public relations and human resources development, and the field of business development moves as a sharing control addressed to the community by Pokdarwis.

According to the interview, political empowerment by the administrators of the village and Padukuhan Dawung has not developed optimally. Due to the quantity of coordination meetings every month, the lack of deliberation among stakeholders in Plempoh Culture Village, there are still many potential joglo (average owned by the society with middle and lower economy) and limasan 
house that has not been packed and has economic value. It has become an indicator that shows the lack of village tour administrators in encouraging and providing protection to the community to play an active role in the development of tourist villages and village tour managers also tend to run independently and unorganized.

Although the coordination leadership among communities in the Cultural Tourism Village of Plempoh is less democratic, conducive conditions still occur in the balance of power distribution among various groups in society. The balance of power distribution can be realized through deliberation, monthly meetings between management and coordination meetings. Governance coordination between the boards takes place every month according to $\mathrm{Mr}$. Dody Heriyanto, but for the coordination meetings between administrators with the community only appears at certain moments, such as when there is an event to be held, and when there are other things that require the holding of the meeting as a discussion.

\section{Level of Empowerment}

There are 5 stages that can be used to measure community empowerment related to planning and development of tourism village, namely: (1) Displacement; (2) Reinforcement; (3) Protection; (4) Support; (5) Maintenance. Based on the community empowerment in Plempoh Cultural Tourism Village of Plempoh in terms of economic, psychological, social and political aspects, it can be described as follows.

\section{a. Level of Economic Empowerment}

In accordance with the realities of economic improvement that can be seen through the increasing of GDP of Bokoharjo Village, the increasing of industries capable of opening employment and the incessant development of infrastructure of village tourism infrastructure, the economic empowerment of society by all stakeholders of Cultural Tourism Village of Plempoh has now reached the fourth stage, namely support stage.

The obvious change is the physical change, namely the improved road and electricity infrastructure. The main roads in the village have been repaired and paved or blocked. According to some people, the changes that occur can be seen with the existence of new buildings such as homestay, meeting joglo, art studio, and clean water facilities. However, the benefits for the tourism sector have not been equally distributed to the community,.

The parties that play the most important roles in the economic empowerment of the community in the village are the Regional Government of Sleman Regency, PT. Taman Wisata Temple and Central of Heritage Center. In addition to providing the necessary facilities and infrastructure in developing the tourism village to be more advanced, the three stakeholders also provide various training that can improve the creativity, ability and skills of the community in

TRJ Tourism Research Journal, Volume 1 (1), 2017 
optimizing the existing natural resources.

The role of other stakeholders in supporting community empowerment economically has not been optimal. For example, the media has not been able to contribute greatly to the promotion of the village. Meanwhile, the effort from academicians in empowering the economy of the community so far is only done through training.

\section{b. Level of Psychological Empowerment}

The implementation of psychological empowerment in Plempoh Cultural Tourism Village is at the second stage/level, namely reinforcement. The results of research shows that Pokdarwis Prabu Boko is able to bridge the enthusiasm of the community in improving all potential both from its nature, culture and society. However, the psychological empowerment by Pokdarwis Prabu Boko has not reached the third stage, namely protection, due to the existing discrimination of community groups caused by the actors responsible for the village potential development. Pokdarwis Prabu Boko has not been able to accommodate the expectations of the community as a whole.

The effort to motivate the community is also done by the academicians through the exploration of the potential of human resources and natural resources that exist in Plempoh Village. There are several activities that have been implemented, such as dance training in accordance with the social story of Plempoh community by Indonesian Art Institute, Plempoh culinary training by STP Ampta, and several other trainings organized by UGM and UNY.

The role of stakeholders at the fourth level is the support from the Sleman and the Yogyakarta Provincial Government through the concept of competition. Psychologically, the community of Cultural Tourism Village of Plempoh is proud of the culture and art that develops its environment, this is because the Cultural Tourism Village of Plempoh several times won the competition as well as gamelan and karawitan competitions organized by provincial and district government.

\section{c. Level of Social Empowerment}

The community social empowerment in Plempoh Village appears at its fifth stage, namely Maintenance. Despite the fact that Pokdarwis is still lacking in integrating the community, Pokdarwis has played a good role in controlling the negative impacts of tourism activities that cause inter-group perceptions and erosion of customs and loss of authenticity possessed by a region. The lack of Pokdarwis ability in carrying out obligations as a comfortable climate creator to coordinate each other and provide transparency related to the solution provided by the central and local government in developing tourist village is a problem that needs to be addressed immediately by the internal Pokdarwis.

So far, the cohesion of rural tourism community has increased along with various agenda of village tourism development from the academics and the

TRJ Tourism Research Journal, Volume 1 (1), 2017 
government side namely PT Taman Wisata Candi. Some of the people who work at PT Taman Wisata Candi are also indigenous people of Plempoh Cultural Tourism Village, thus the social interaction in interpersonal work is happening more visible considering not only the customs that make people interact with each other.

\section{d. Level of Political Empowerment}

The existing political empowerment in Plempoh Village is the empowerment which is at the lowest level, which is possibility; referring to most of the people of the Cultural Tourism Village of Plempoh claimed not to be involved in problem identification and in decision making related to tourism village development. They were never invited into dialogues in identifying the needs of local communities. This happens because (1) the idea of developing a tourist village is done by the Sleman Regency Government without involving the community as the owner of the resources, so that the people of Plempoh Cultural Tourism Village do not understand the background of the development of the tourist village; (2) the local community is only doing what the government is bred for, for example, the willingness to accept tourist arrivals and to hand over land for tourism facilities; and (3) the local community is not empowered to participate actively in the sense of contributing to the decision of the top-down rulers.

In terms of the liveliness of the community Cultural Tourism Village of Plempoh, the results of the study found that in fact the presence of residents in village meetings appears quite enthusiastic. However, in general they claim not to be involved in decision-making regarding the development of tourist villages. In terms of community representation at meetings, usually the stakeholders only invite some residents who have not adequately represented the presence of each group such as youth and women groups.

The involvement of local communities in monitoring the development of tourist villages appears minimal. The reason is that the development planning is done by the top-down government, so the community is not competent to conduct supervision, and ultimately, the community chooses to participate in preventive controls to prevent negative actions that could disturb the village security. So far, complex supervision has been carried out only by a handful of critical communities including the elite of the local community.

\section{E. Conclusion}

Based on the description, the analysis and discussion of research results on Community Empowerment of Cultural Tourism Village of Plempoh, it can be concluded that the empowerment efforts undertaken by village stakeholders have not been optimal, this is because some of the tourism village stakeholders still have not given strong commitment but less trust towards local communities as subjects in the development of the Cultural Tourism Village of Plempoh.

TRJ Tourism Research Journal, Volume 1 (1), 2017 
However, it does not mean that the implementation of the empowerment project does not show progress at all.

According to the realization of economic improvement, the economic empowerment of the community by all stakeholders of the Cultural Tourism Village of Plempoh has now reached the fourth stage, namely support stage. The parties that play the most important roles in the economic empowerment of the people of Plempoh Cultural Tourism Village are the Regional Government of Sleman Regency, PT. Taman Wisata Temple and Central of Heritage Center. In addition to providing the necessary facilities and infrastructure in developing the tourism village to be more advanced, the three stakeholders also provide various training that can improve the creativity, ability and skills of the community in optimizing the existing natural resources.

The realization of psychological empowerment in Plempoh Cultural Tourism Village is at the second stage/level, namely reinforcement. The research shows that Pokdarwis Prabu Boko is able to bridge the enthusiasm of the community in improving all its potential from its nature, culture and society. The effort to motivate the community is also done by the academicians through the exploration of the potential of human resources and natural resources that exist in Plempoh Village. The role of stakeholders at the fourth level is the support from Sleman and Yogyakarta Provincial Government through the concept of competition. Psychologically, the people of Plempoh Cultural Tourism Village are proud of the culture and art that develop in their environment.

Social empowerment of the community of Plempoh Cultural Tourism Village is at its fifth stage, which is Maintenance. Despite the fact that Pokdarwis is still lacking in integrating community in society, it has played a good role in controlling the negative impacts of tourism activities that cause inter-group perceptions, erosion of customs and loss of authenticity possessed by a region. So far, the cohesion of rural tourism community has increased along with various agendas of village tourism development from the government side, PT Taman Wisata Candi and also academicians. In addition, the central, provincial and local governments play a very active role in the social empowerment of communities. Funding proposed for community development such as infrastructure provision is a manifestation of government involvement in advancing this tourism village.

The existing political empowerment in Plempoh Village is the empowerment at the lowest level, namely possibility. Most of the people of Plempoh Cultural Tourism Village claimed not to be involved in problem identification and decision making related to tourism village development. The involvement of local communities in monitoring the development of tourist villages is minimal. The reason is that the development planning is done by the top-down government, so the community is not competent to conduct supervision, and ultimately, the community chooses to participate in preventive

TRJ Tourism Research Journal, Volume 1 (1), 2017 
supervision. So far, complex supervision has been carried out only by a handful of critical communities including the community elites. The level of political empowerment that remains at the level of possibility is a problem that must be resolved by the internal tourist village. Communities need to be more often invited to dialogue to identify their needs. In addition, community representation at meetings should be more complex by inviting people who are able to represent each group including youth and women.

The psychological empowerment by Pokdarwis Prabu Boko has not reached the third stage, which is protection; since discrimination still exists among the community because the actors who become inspiratory of tourism village potential development are only followed by the same people. Therefore, Pokdarwis Prabu Boko must be able to accommodate the expectations of society as a whole. Increasing the quantity and quality of training in accordance with the conditions of society is one of the ways that needs to be done.

Community empowerment effort in Plempoh Cultural Tourism Village is a long and challenging road. Only with strong commitment, determination and sincerity, community empowerment can be done successfully. This commitment can be realized in the form of giving the trust to the community for the development of Plempoh Cultural Tourism Village in accordance with the basic needs of local community.

\section{F. Acknowledgement}

Our thanks and appreciations go to the people who directly or indirectly helped us in doing the research. Bapak Suparno, Bapak Gianto, Ibu Karsini, Ibu Ismi, Bapak Sardi, Bapak Aris Gunadi, and Mashud Idris.

\section{REFERENCES}

Badan Pusat Statistik Kabupaten Sleman. (2015). Kecamatan Prambanan Dalam Angka Tahun 2014: Badan Pusat Statistik.

Dewi, M.H.U., Fandeli, C., Baiquni, M. (2013). Pengembangan Desa Wisata Berbasis Partisipasi Masyarakat Lokal di Desa Wisata Jatiluwih Tabanan, Bali. Kawistara, 3(2). 129-139.

(2016). Laporan Statistik Kepariwisataan Daerah Istimewa Yogyakarta 2015. Yogyakarta: Dinas Pariwisata

DIY, D. (2014). Sejarah Singkat Provinsi Daerah Istimewa Yogyakarta dikpora.Jogjaprov.Go.Id. Retrieved December 2, 2016, from http://pendidikandiy.go.id/dinas $\mathrm{v} 4 /$ ? view $=$ baca isi lengkap\&id $\mathrm{p}=1$

Hermantoro, H. (2015). Kepariwisataan, Destinasi Pariwisata, Produk

TRJ Tourism Research Journal, Volume 1 (1), 2017 
Pariwisata. Depok: CV. Aditri.

Kemenparekraf. (2012). Buku Pedoman Kelompok Sadar Wisata. Retrieved from http://www.kemenpar.go.id/userfiles/1 \%20Pedoman\%20Pokdarwis.pd $\underline{f}$

Knight, D.W. (2015). Evaluating Tourism-linked Empowerment in Cuzco, Peru. Annals of Tourism Research, 56(2016). 32-47.

Li, Y., \& Hunter, C. (2015). Community Involvement for Sustainable Heritage Tourism: a Conceptual Model. Journal of Cultural Heritage Management and Sustainable Development, 5(3), 248-262. doi:10.1108/JCHMSD-08-2014-0027.

Martono, H., Pujiastuti, S., Pratiwi, E., \& Chrysandi, G. (2013). Koreografi Lingkungan Masyarakat Plempoh, Prambanan, Daerah Istimewa Yogyakarta. Journal of Urban Society's Arts, 13(2), 132-142.

Maryani, E., \& Waluya, B. (2008). Mata Kuliah Geografi Desa Kota. Bandung: UPI.

Nalayani, N.N.A.H., (2016). Evaluasi dan Strategi Pengembangan Desa Wisata di Kabupaten Badung, Bali. JUMP A, 2(2). 189-198

Perda Kabupten Sleman Nomor 12 Tahun 2012 Tentang Rencana Tata Ruang Wilayah Kabupaten Sleman Tahun 2011-2031. Sleman: Sekda Kab. Sleman.

Pitana, I. G., \& Gayatri, P.G. (2005). Sosiologi pariwisata. Yogyakarta: Andi.

PPRI No. 50 Tahun 2011 Tentang Rencana Induk Pembangunan Kepariwisataan Nasional Tahun 2010 - 2025. Lembaran Negara RI Tahun 2011, No. 125. Jakarta: Kemensekneg

Purnamasari, I. (2008). Studi Partisipasi Masyarakat Dalam Perencanaan Pembangunan Di Kecamatan Cibadak Kabupaten Sukabumi. Semarang: Program Pascasarjana UNDIP

Purnamasari, I.K. (2011). Pemberdayaan Masyarakat Melalui Desa Wisata dalam Usaha Peningkatan Kesejabteraan, Desa Candirejo Kabupaten Magelang (Thesis). Fakultas Ekonomi UI, Jakarta.

Putra, T.R. (2013). Peran Pokdarwis dalam Pengembangan Atraksi Wisata di Desa Wisata Tembi, Kecamatan Sewon, Kabupaten Bantul. Jurnal Pembangunan Wilayah dan Kota.

Qiqi, D., \& Rova, L. (2014). Tourism Development and Human Resources Challenges (Gjirokastra Region). Eouropean Journal of Sustainable Development, 3(3), 211-218. doi:10.14207/ejsd.2014.v3n3p211

Ramafriani, B. (2012). Studi Tatanan Lanskap Situs Ratu Boko, Daerah Istimewa Yogyakarta dan Upaya Pelestariannya (Skripsi). Departemen Arsitektur Lanskap Fakultas Pertanian IPB, Bogor.

Scheyvens, R. (1999). Ecotourism and the Empowerment of Local Communities. Tourism Management 20. 245-249. DOI: 10.1016/S02615177(98)00069-7

Setda Kabupaten Sleman. (2014). Daftar Isian, Data Dasar Profil Desa 
Bokoharjo.

Smith, M., \& Robinson, M. (2005). Cultural Tourism in a Changing World Politics, Participation and Re-presentation. Great Britain: Cromwell Press.

Sofianto, A. (2013). Peran Kelompok Masyarakat dalam Penguatan Inovasi Sosial di Desa Karangrejo, Kecamatan Borobudur, Kabupaten Magelang. Jurnal Litbang Provinsi Jawa Tengah.

Stetic, S., Pavlovic, S., Stanic, S., \& Simicevic, D. (2014). Dimensions of Integrated Tourism - Case Studies of Selected Villages in the SerbiaRomania Border Area. Journal of Settlements and Spatial Planning, 80-88.

Suharto, E. (2006). Pengampingan Sosial dalam Pemberdayaan Masyarakat Miskin: Konsepsi dan Strategi. Retrieved December 18, 2016, from http://www.policy.hu/suharto/modul a/makindo 32.htm

Wijaya. D.A. (2009). Pengembangan Pariwisata Berbasis Masyarakat di Desa Wisata Plempoh Bokoharjo Sleman Yogyakarta. Jurnal Pariwisata Indonesia, 5(1). 1-14. 